\title{
Energy recovery from poultry manure: a viable solution to reduce poultry industry energy consumption
}

\author{
Gheorghe LAZAROIU (a , Dana-Alexandra CIUPAGEANU (a) Lucian MIHAESCU ${ }^{\text {(b }}$, \\ Manuela GRIGORIU (a, Iulia SIMION ${ }^{\text {a }}$ \\ a) Power Engineering Faculty, University Politehnica of Bucharest \\ b) Mechanics and Mechatronics Faculty, University Politehnica of Bucharest \\ Splaiul Independentei 313, 060042 Bucharest (Romania) \\ e-mails: glazaroiu@yahoo.com, dana ciupageanu@yahoo.com, 1mihaescu@caz.mecen.pub.ro, \\ manuela.grigoriu.1968@gmail.com, julia.simion@gmail.com
}

\begin{abstract}
As the global energy demand shows a steady growth, the energy framework becomes more restrictive in reference to the environmental impact and judicious use of resources. In this context, energy recovery from renewable waste stands out as a promising technology to deal with large amounts of different wastes while producing energy. This paper addresses the poultry manure waste treatment from the energy recovery perspective. After a brief overview of available technologies for energy valorization of animal manure, the physical-chemical characteristics of poultry manure are investigated through experimental determinations. Further, a case study is presented in reference to the energy recovery potential of a birdhouse with a livestock of 2000 birds per cycle, located in Southern Romania. The assessment carried out within this research proves that, by locally using the poultry manure as a feedstock for energy generation, the savings in terms of electricity consumption get to $100 \%$. Moreover, it is no longer necessary to store large quantities of waste.
\end{abstract}

Key words. energy recovery, energy saving, poultry manure, renewable waste, waste treatment.

\section{Introduction}

During the past decades, research interest in the energy field focuses on harmful emissions abatement and renewable energy technologies development and integration [1]. According to statistics released by the International Renewable Energy Agency [2], it is remarked as renewable energy sources (RES) almost doubled their cumulated generating capacity over the last decade. However, their strong variability, both temporal and spatial, requires particular attention from the system's operator point of view [3], [4].

One of the hot topics related to RES is the integrative approach comprising energy recovery from renewable waste, which, for now gathers less than $4.5 \%$ of the total RES [2]. Fig. 1 depicts the evolution of the generating capacities supplied by solid biomass/renewable waste. It is evident that approximately $30 \%$ of the global capacity is located within the European Union, of which the highest share corresponds to UK (around 20\% last year). The great advantage of this approach relies on its double sided implication energy production/waste treatment [5], [6].
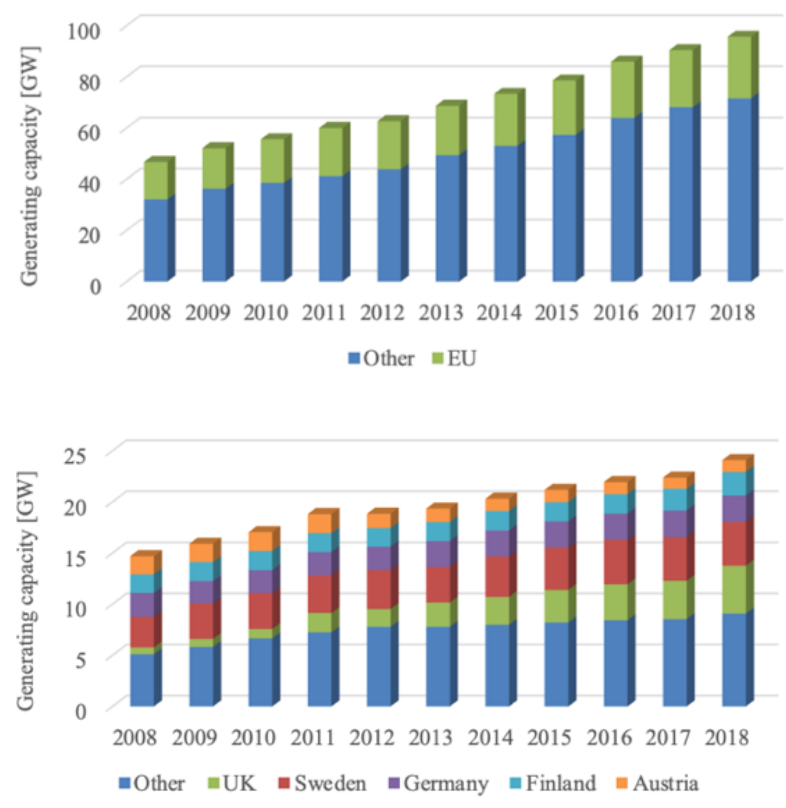

Fig. 1. Generating capacities using renewable waste: worldwide (upper figure) and in European Union (lower figure)

Food industry and agricultural sector generate large quantities of renewable waste every year [7], [8]. Given the intensive poultry industry products consumption (chicken meat, eggs, etc.), the resulting waste has to be carefully managed. Dead birds have to be disposed according to particular regulation (EU Regulation 1774/2002), but the remaining litter can be found useful in multiple ways [9]. 
For instance, waste mixtures resulting from bird houses operating cycles are characterized by increased soil restoration potential, so an alternative for their management is by land spreading (as fertilizers). However, limitations regarding Nitrogen content in agricultural areas imposed by 91/676/CEE Directive (poultry manure may show high Nitrogen composition) emphasize the need to intensively consider other management approaches, such as treatments with energy recovery potential [10].

This paper tackles with the poultry manure management for energy recovery purposes. To this aim, the physical and chemical characteristics of poultry manure samples (from a birdhouse in Romania) are evaluated and results are depicted in Section 3. Next, Section 4 presents a Case Study envisaging the estimation of the energy saving potential if the poultry manure resulting from a 2000 birds livestock/cycle birdhouse would be employed as feedstock, based on real data records from a poultry farm. Finally, conclusions are drawn in the last section.

\section{Estimated energy recovery potential}

\section{A. Process technologies}

Aerobic biological treatment (with or without separation) enables Nitrogen retention through nitrification. It is remarked that, in some conditions, harmful nitrous oxides can be formed, which is a great disadvantage of this method [11]. Anaerobic digestion involves waste's organic fraction digestion by microorganisms (lacking oxygen), resulting in a mixture consisting of $55-75 \%$ methane (biogas). The estimated biogas production if using poultry manure as feedstock is $\mathbf{0 . 2 2} \mathbf{m}^{\mathbf{3}} / \mathbf{k g}_{\text {manure }}$ [12] and can be further employed for energy purposes.

Thermo-chemical waste treatment (pyrolysis, gasification, direct combustion, etc.) is a frequently addressed alternative. Basically, during pyrolysis fixed carbon is separated from the volatile matter by cooking the waste at temperatures below $\mathbf{6 0 0}^{\circ} \mathrm{C}$ [13]. A mixture composed by carbon monoxide and methane (Syngas) is obtained. Researches in the field proved that, under specific conditions, a useful pure Hydrogen flow can be obtained in gasification processes. It is estimated that a $30 \%$ efficiency of poultry manure gasification can be reached [14]. Regarding the direct combustion process, investigations carried out in literature report that a net electricity production in the range $(0.75-1.15) \mathrm{kWh} / \mathrm{kg}_{\text {manure }}$ is achievable for poultry manure. The main drawback of this technology is $N O_{x}$ generation during burning [15]

\section{B. Poultry livestock in Romania}

Statistical records available [16] show that Romania accounts for a poultry production of approximately 80000 birds/year. Moreover, its territorial spread across the country is quite uniform, so using poultry manure as combustible feedstock for some local industries would not raise significant transportation problems.

\section{Physical and chemical characteristics of poultry manure}

Poultry manure is usually composed by different ratios of chicken droppings, feathers, birdhouse floor bedding (sawdust or cereal straws) and food scraps. Therefore, it has a granular consistency, highly heterogeneous, with poor energy characteristics (especially if the moisture content is high) [17]. Its appearance can vary, depending on the moisture content, from compact wet manure to a dusty powder. Direct combustion of poultry manure enables retaining some elements in the ash, such as Phosphorus and Potassium, while Nitrogen is dispersed in the burning process [10], [18]. Compared to other animal manures, poultry in particular has a very high Phosphorus content (mainly in soluble acid fraction), reaching $2.5 \%$ in dry sample, depending on the chosen diet [19].

The high heterogeneity of poultry manure represents a factor which disrupts its employment for energy purposes. The lower heating value $\left(H_{i}\right)$ of waste samples (here, poultry manure) can be determined directly, through calorimetric methods, or through indirect empirical estimation based on prior elemental analysis [11], [17], according to eq. (1).

$$
\begin{array}{r}
H_{i}=2.336 \cdot[145 \cdot C+610 \cdot(H-0.125 \cdot O) \\
+40 \cdot S+10 \cdot N][\mathrm{kJ} / \mathrm{kg}]
\end{array}
$$

where $C, H, O, S$ and $N$ are the weight percentages of the chemical elements, resulted from elemental analysis.

Table 1 depicts the results of the elemental analysis performed over poultry manure samples collected from a birdhouse located in Romania. It is evident that they fall within the limits presented in related scientific literature [10], [13], [20].

Table 1. Elemental analysis of poultry manure

\begin{tabular}{|l|l|l|l|}
\hline Element & \multirow{2}{*}{$\begin{array}{l}\text { Experimental } \\
\text { value }\end{array}$} & \multicolumn{2}{|c|}{ Literature values } \\
\cline { 3 - 4 } & & Average & $\begin{array}{l}\text { Standard } \\
\text { deviation }\end{array}$ \\
\hline $\mathrm{C}$ & 36.22 & 29.54 & 12.25 \\
\hline $\mathrm{H}$ & 1.14 & 2.47 & 1.47 \\
\hline $\mathrm{N}$ & 3.52 & 2.88 & 1.34 \\
\hline
\end{tabular}

Based on the results listed in Table 1 and according to eq. (1), the lower heating value determined for the poultry manure under study results $H_{i}=3.44 \mathrm{MJ} / \mathrm{kg}_{\text {manure }}$.

\section{Case study}

Further, a case study is presented. A set of geometrical characteristics and energy consumption data from a real poultry farm located in Southern Romania is considered. It is necessary to highlight that temperature regulation in the early stages of poultry meat production (first four weeks) is very important, especially if the birdhouse is placed in temperate or cold areas. This process includes an external heating source (usually fueled by fossil fuels) though heat requirements are diminished at later stages of chickens 
lifecycle [21]. Obviously, this additional energy consumption increases production costs. A cost-saving measure often implemented is to reduce the hall ventilation. As a consequence, birds' health is negatively affected (dermatitis can occur), rises the humidity content (including for what concerns the manure) and facilitates the accumulation of toxic gases, such as ammonia and carbon monoxide (causing even mortality if concentrations reach high values). Poultry manure is cleaned at the end of each cycle, after the depopulation of the birdhouse. According to the best available technique, the recommended surface density for poultry breeding falls within the limits of $14-$ $18 \mathrm{birds} / \mathrm{m}^{2}$. Each breeding cycle takes 42 days [13], [19].

\section{A. Modelling hypotheses}

Given the importance of not only numerical values, but also the spatial distribution of inside breeding halls parameters, several models have been introduced over the years in the literature. For detailed representations, Computational Fluid Dynamics has been employed as well, both for stationary and dynamic conditions [21]. In this study, a real bird house geometry is considered, as pictured in Fig. 2.

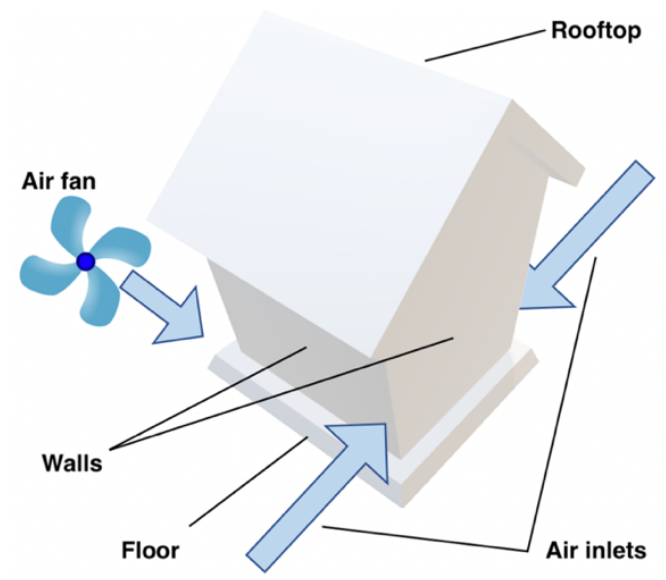

Fig. 2. Birdhouse layout

Furthermore, Fig. 3 emphasizes the heat fluxes generally exchanged within a birdhouse and with the outer environment.

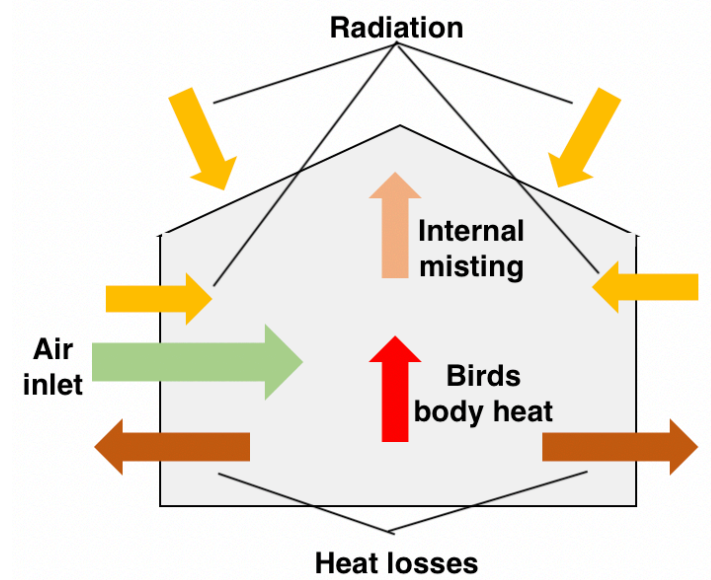

Fig. 3. Heat exchanges
Thermal balance is evaluated considering that inside the birdhouse the temperature varies with the distance from sidewalls as $T \cdot x$, based on the equilibrium of the differential element $d x$, as pictured in Fig. 4.

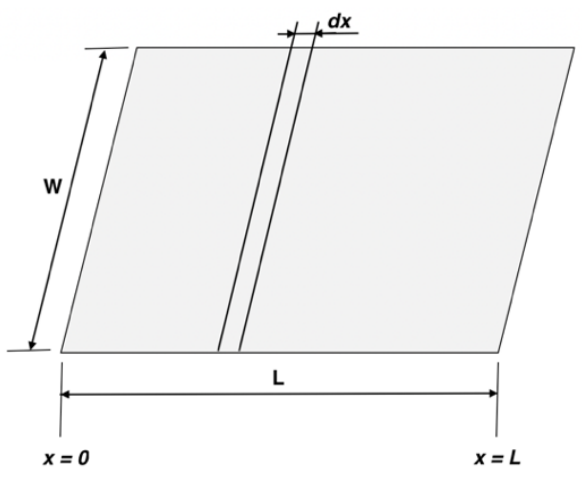

Fig. 4. Birdhouse floor geometry

More in detail, the heat exchanges are evaluated for each inlet as it follows:

- Inlet 1: radiative heat flux

$$
\begin{gathered}
Q_{r}=\left(Q_{r-i}+Q_{r-d}\right) \cdot A_{\text {roof }} \cdot S_{\text {roof }}+ \\
Q_{r-d} \cdot A_{\text {walls }} \cdot S_{\text {walls }}
\end{gathered}
$$

where: $Q_{r-i}\left[W / m^{2}\right]$ and $Q_{r-d}\left[W / m^{2}\right]$ are the incident and diffusive radiative fluxes; $A_{\text {roof }}\left[\mathrm{m}^{2}\right]$ and $A_{\text {walls }}\left[\mathrm{m}^{2}\right]$ are the areas of the rooftop and lateral walls respectively; $S_{\text {roof }}[-]$ and $S_{\text {walls }}[-]$ are the shading factors.

- Inlet 2: airflow heat flux

$$
Q_{\text {air }}=\dot{V} \cdot \rho \cdot c_{p} \cdot T_{a}
$$

where: $\dot{V}\left[\mathrm{~m}^{3} / \mathrm{s}\right]$ is the airflow circulated by the fans; $\rho\left[\mathrm{kg} / \mathrm{m}^{3}\right]$ is the air density; $c_{p}[\mathrm{~J} / \mathrm{kg} \cdot \mathrm{K}]$ is the specific mass heat of air and $T_{a}[K]$ is the air inlet temperature.

- Inlet 3: birds body heat flux

$$
Q_{\text {birds }}=N \cdot q_{\text {bird }}
$$

where: $N$ is the total number of birds and $q_{\text {bird }}[W /$ bird $]$ is the body heat of each bird.

- Inlet 4: internal misting heat flux $\left(Q_{m}[W]\right)$

- Outlet: conductive heat losses

$$
Q_{\text {loss }}=\left(A_{\text {roof }} \cdot H_{\text {roof }}+A_{\text {walls }} \cdot H_{\text {walls }}\right) \cdot \Delta T
$$

where: $H_{\text {roof }}$ and $H_{\text {walls }}$ are the heat transfer coefficients for the rooftop and side walls respectively.

- Accumulated heat

$$
Q_{\text {acc }}=\Delta V \cdot \rho \cdot c_{p} \cdot T_{\text {int }}
$$

where: $\Delta V\left[\mathrm{~m}^{3} / \mathrm{s}\right]$ is the airflow variation between air inlet and ventilation extracted air from the birdhouse and $T_{\text {int }}[K]$ is the temperature to be kept constant. 
The thermal balance respects eq. (7), as it is detailed forward, where the only unknown variable remains the necessary temperature to be achieved for the airflow inlet, so that the temperature inside the hall can be kept constant (which, for the following evaluations, is considered uniformly distributed).

$$
Q_{a c c}=Q_{r}+Q_{a i r}+Q_{\text {birds }}+Q_{m}-Q_{\text {loss }}
$$

Hence, the unknown temperature needed results as:

$$
T_{a}=\frac{Q_{a c c}+Q_{\text {loss }}-Q_{b i r d s}-Q_{m}-Q_{r}}{\dot{V} \cdot \rho \cdot c_{p}}
$$

\section{B. Numerical application}

In the following, a numerical application is considered in order to quantitively evaluate the energy recovery potential of a particular birdhouse configuration. Moreover, the energy savings achievable by implementing a direct combustion installation for poultry manure energy valorization is estimated. The hall is considered to be placed in the southern region of Romania, where the solar irradiation reaches $1200 \mathrm{kWh} / \mathrm{m}^{2}$-year, with an average duration of $2250 \mathrm{~h} /$ year, resulting in $535 \mathrm{~W} / \mathrm{m}^{2}$ direct incident radiation [22]. Moreover, an average external temperature of $T_{a}=15^{\circ} \mathrm{C}$ is taken into account [16]. The related data is listed in Table 2.

Table 2. Numerical data

\begin{tabular}{|l|c|c|}
\hline Air inside temperature & $T_{\text {int }}$ & $25^{\circ} \mathrm{C}$ \\
\hline Air specific heat & $c_{p}$ & $10^{3} \mathrm{~J} / \mathrm{kg}$ \\
\hline $\begin{array}{l}\text { Air density in normal } \\
\text { conditions }\end{array}$ & $\rho$ & $1.15 \mathrm{~kg} / \mathrm{m}^{3}$ \\
\hline Air fans flow transfer & $H_{\text {roof }}$ & $1.75 \mathrm{~W} / \mathrm{m}^{2} \cdot \mathrm{K}$ \\
\hline $\begin{array}{l}\text { Heat transfer } \\
\text { coefficient for the } \\
\text { rooftop }\end{array}$ & $H_{\text {walls }}$ & $5.65 \mathrm{~W} / \mathrm{m}^{2} \cdot \mathrm{K}$ \\
\hline $\begin{array}{l}\text { Heat the } \\
\text { coefficient for } \\
\text { walls }\end{array}$ & $Q_{r-i}$ & $535 \mathrm{~W} / \mathrm{m}^{2}$ \\
\hline $\begin{array}{l}\text { Direct solar radiation } \\
\text { on the rooftop }\end{array}$ & $Q_{r-d}$ & $7.5 \mathrm{~W} / \mathrm{m}^{2}$ \\
\hline $\begin{array}{l}\text { Diffuse solar radiation } \\
\text { incident on the rooftop }\end{array}$ & $S_{\text {walls }}$ & 1 \\
\hline $\begin{array}{l}\text { Shading factor for the } \\
\text { walls }\end{array}$ & $S_{\text {roof }}$ & 0.7 \\
\hline $\begin{array}{l}\text { Shading factor for the } \\
\text { rooftop }\end{array}$ & $q_{\text {bird }}$ & $7.75 \mathrm{~W} / \mathrm{bird}$ \\
\hline Bird heat radiation
\end{tabular}

More in detail, a livestock of 2000 birds/operative cycle is considered. According to data provided by a real poultry industry enterprise, the manure flux from the birdhouse reaches $M=14.3 t /$ day. The geometric characteristics of the hall are listed forward:

- Length: $L=96 \mathrm{~m}$;

- Width: $W=18 \mathrm{~m}$;

- Height: $H=3.8 \mathrm{~m}$;

- Ground floor area: $A_{\text {roof }}=1728 \mathrm{~m}^{2}$;
- Sidewalls area: $A_{\text {walls }}=866.4 \mathrm{~m}^{2}$;

- Rooftop area: $A_{\text {roof }}=2160 \mathrm{~m}^{2}$.

Now, knowing all the quantities involved, each heat flux is evaluated, as it follows:

- Inlet 1: $Q_{r}=1176.35 \mathrm{~kW}$

- Inlet 3: $Q_{\text {birds }}=15.50 \mathrm{~kW}$

- Inlet 4: $Q_{m}=103.19 \mathrm{~kW}$

- Outlet: $Q_{\text {loss }}=86.75 \mathrm{~kW}$

- Accumulated: $Q_{a c c}=1627.83 \mathrm{~kW}$

According to eq. (8), the required temperature of the air inlet has to be equal to $T_{a}=39.70^{\circ} \mathrm{C}$. Considering the average ambient temperature mentioned previously $\left(T_{0}=\right.$ $\left.15^{\circ} \mathrm{C}\right)$, the inside/outside temperature difference is estimated to $\Delta T=10^{\circ} \mathrm{C}$. Hence, the energy required to heat the inlet air flow to the necessary value is evaluated to $Q_{r e q}^{t h}=33.13 \mathrm{~kW}$; if the electrical to thermal energy conversion efficiency is equal to $\eta_{1}=0.97$, then $Q_{r e q}^{e l}=$ $34.16 \mathrm{~kW}$. In terms of daily energy, for a continuous operation of the heating system, this value translates to $W_{\text {req }}^{\text {heat }}=819.81 \mathrm{kWh}$. Taking into account $W_{\text {req }}^{\text {ventilation }}=3120 \mathrm{kWh}[23]$ and an estimated additional consumption (related to lightning, cleaning, humidification, etc.) of $W_{\text {req }}^{\text {additional }}=1900 \mathrm{kWh}$, the total daily energy consumption of the regarded birdhouse adds up to $W_{\text {req }}=5852.61 \mathrm{kWh}$.

If the resulted poultry manure is disposed by direct combustion on a daily basis, the resulting energy recovered is evaluated as it follows:

$$
W_{\text {manure }}^{e l}=M \cdot H_{i} \cdot \eta_{2}
$$

We take into account the energy conversion facility consisting of a boiler $\left(\eta_{b}=0.90\right)$, a steam turbine $\left(\eta_{t}=\right.$ $0.45)$ and an electrical generator $\left(\eta_{g}=0.98\right)$, so the average overall efficiency of the thermal to electrical energy conversion system results as the product of the three efficiencies, $\eta_{2}=0.40$ [24]. Specifically, the electricity generated using the energy potentially recoverable is evaluated to $W_{\text {manure }}^{\text {el }}=5418 \mathrm{kWh}$. Therefore, it is proven that the energy recovery from poultry manure waste can satisfy over $90 \%$ of the energy demand of the birdhouse under study. It is highlighted that the evaluations performed in this paper takes into account a slight overestimation of the energy consumption. Therefore, it is very likely to reach energy independence of a poultry house based on direct combustion of the resulting poultry manure.

Considering an average price of energy of 0.136 Euro/ $k W h$ on the Romanian electricity market [25], the total yearly cost savings due to the self-supplied energy requirements adds up to 290524 Euro. This results in an investment recovery rate under 10 years, which falls within the generally accepted limits. 


\section{Conclusions}

Energy recovery from solid biomass/renewable waste sources represent an intensively analyzed option in the RES integration framework, with additional benefits from the waste management point of view. This paper discusses the poultry manure treatment through direct combustion for energy recovery purposes. Experimental investigations are conducted to determine the elemental composition of poultry manure samples collected from a birdhouse in Romania. The lower heating value is evaluated and the electricity generation potential is assessed based on these results. The geometric characteristics of the real poultry hall are employed in assessing the energy saving potential. The outcomes of this research emphasize that poultry halls can reach full independence $(100 \%$ balancing of the demand) through using the poultry manure in an energy recovery oriented facility. Furthermore, this approach tackles the waste storage/transportation issues by its local employment, proving to be a sustainable solution.

\section{Acknowledgement}

This work was supported by a grant from the Romanian Ministry of Research and Innovation, CCCDIUEFISCDI, project number PN-III-P1-1.2-PCCDI-20170404/31PCCD/2018, within PNCDI.

\section{References}

[1] International Renewable Energy Agency, "International Renewable Energy Agency: Renewable Energie: A Key Climate Soluation,” 2017.

[2] International Renewable Energy Agency, "RENEWABLE CAPACITY STATISTICS 2019," 2019.

[3] T. Adefarati and R. C. Bansal, "Integration of renewable distributed generators into the distribution system: a review," IET Renew. Power Gener., 2016.

[4] O. Udrea and G. Lazaroiu, "RES INTEGRATION IN ROMANIA," U.P.B. Sci. Bull., Ser. C, 2015.

[5] R. Kothari, V. V. Tyagi, and A. Pathak, "Waste-toenergy: A way from renewable energy sources to sustainable development," Renewable and Sustainable Energy Reviews. 2010.

[6] G. Lăzăroiu, R. C. Mocanu, A. D. Bondrea, E. M. Mavrodin, and L. Balanescu, "Use of animal fat waste as a bio-fuel," in International Multidisciplinary Scientific GeoConference Surveying Geology and Mining Ecology Management, SGEM, 2017.

[7] M. F. Demirbas, M. Balat, and H. Balat, "Potential contribution of biomass to the sustainable energy development," Energy Convers. Manag., 2009.

[8] G. Lazaroiu et al., "Solutions for energy recovery of animal waste from leather industry," Energy Convers. Manag., 2017.

[9] F. Santos Dalolio et al., "Poultry litter as biomass energy: A review and future perspectives," Renew. Sustain. Energy Rev., vol. 76, pp. 941-949, 2017.

[10] F. Cotana, V. Coccia, A. Petrozzi, G. Cavalaglio, M. Gelosia, and M. C. Merico, "Energy valorization of poultry manure in a thermal power plant: Experimental campaign," Energy Procedia, vol. 45, pp. 315-322, 2014.

[11] E. Brizio and G. Genon, "Environmental compatibility of renewable energy plants," WIT Trans. Ecol. Environ., vol. 136, pp. 149-159, 2010.

[12] L. Loyon, "Overview of manure treatment in France," Waste Manag., vol. 61, pp. 516-520, 2017.

[13] L. Mihaescu, G. Lazaroiu, I. Pisa, D.-A. Ciupageanu, and V. Berbece, "Energy valorization of poultry manure through products resulted in a pyrolysis process," in 18th International Multidisciplinary Scientific GeoConference SGEM2018, 2018, pp. 349-355.

[14] G. Cavalaglio, V. Coccia, F. Cotana, M. Gelosia, A. Nicolini, and A. Petrozzi, "Energy from poultry waste: An Aspen Plus-based approach to the thermo-chemical processes," Waste Manag., vol. 73, pp. 496-503, 2018.

[15] G. Lazaroiu et al., "Experimental Investigations of Innovative Biomass Energy Harnessing Solutions," Energies, vol. 11, no. 12, p. 3469, 2018.

[16] National Institute of Statistics, "Anuarul Statistic al Romaniei," 2013.

[17] G. Quiroga, L. Castrillón, Y. Fernández-Nava, and E. Marañón, "Physico-chemical analysis and calorific values of poultry manure," Waste Manag., vol. 30, no. 5, pp. 880-884, 2010.

[18] L. Mihaescu, G. Lazaroiu, I. Pisa, G.-P. Negreanu, V. Berbece, and D.-A. Ciupageanu, "Thermal conditions required for poultry manure combustion in furnace boilers," in 19th International Multidisciplinary Scientific Geoconference SGEM2019, Volume 19(4.1), 2019, pp. 569-576.

[19] C. R.-N. Joseph R. V. Flora, "Availability of poultry manure as a potential bio-fuel feedstock for energy production," 2006.

[20] P. De Filippis, M. Scarsella, N. Verdone, and M. Zeppieri, "Poultry litter valorization to energy," WIT Trans. Ecol. Environ., vol. 109, pp. 261-267, 2008.

[21] J. A. Osorio Saraz, I. F. F. Tinôco, K. S. Oliveira Rocha, M. A. Martins, and M. de Paula, "Modeling and experimental validation to estimate the energy balance for a poultry house with misting cooling [Modelamiento y validación experimental para determinar un balance de energia en un galpon avicola con nebulización interna]," DYNA, vol. 78, no. 170, pp. 167-174, 2011.

[22] "https://solargis.com/maps-and-gis-data.".

[23] "https://www.engineeringtoolbox.com/fans-efficiencypower-consumption-d 197.html.”.

[24] X. Liu and R. Bansal, Thermal Power Plants. 2016.

[25] "https://ec.europa.eu/eurostat/statisticsexplained/index.php/Electricity_price_statistics," European Comission Statistics. 